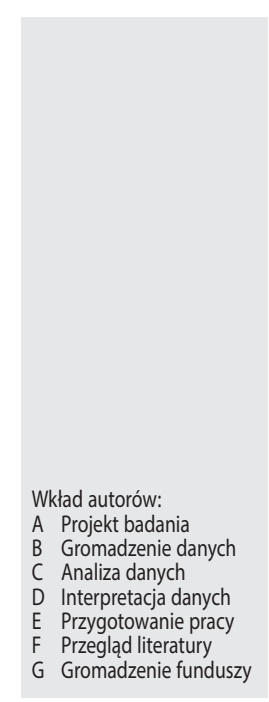

\title{
Jakość życia rodzin z dzieckiem z centralnymi zaburzeniami przetwarzania słuchowego
}

\section{The quality of life of families with a child with a central auditory processing disorder}

\author{
Joanna Kobosko ${ }^{1, A, C-F}$, Małgorzata Ganc ${ }^{1, A-C, E}$, Anna Skoczylas ${ }^{2, D-F}$, \\ W. Wiktor Jędrzejczak ${ }^{1, C-E}$, Henryk Skarżyński ${ }^{3 G}$
}
${ }^{1}$ Instytut Fizjologii i Patologii Słuchu, Zakład Audiologii Eksperymentalnej, Warszawa/ Kajetany
${ }^{2}$ Instytut Fizjologii i Patologii Słuchu, Klinika Rehabilitacji, Warszawa/Kajetany
${ }^{3}$ Instytut Fizjologii i Patologii Słuchu, Warszawa/Kajetany

\section{Streszczenie}

Wprowadzenie: W myśl podejścia skoncentrowanego na rodzinie (FCA) to rodzina odgrywa wiodącą rolę we wspieraniu dziecka z zaburzeniami słuchu w rozwoju, leczeniu i rehabilitacji. Jakość życia rodziny staje się zarówno celem interdyscyplinarnej diagnozy, jak i podejmowanych oddziaływań na jej rzecz. Jak dotąd nie ma badań nad jakością życia rodzin z dzieckiem z centralnymi zaburzeniami przetwarzania słuchowego (APD). W niniejszym badaniu postawiono pytanie o jakość życia rodzin z dzieckiem z APD, zwłaszcza w obszarze wsparcia specjalistycznego i wsparcia społecznego, oraz porównano jakość życia rodzin z dzieckiem z APD z jakością życia rodzin z dziećmi z różnymi niepełnosprawnościami.

Materiał i metody: Badaniami objęto 38 rodzin z dziećmi z APD w wieku średnio 9,8 lat. Rodzice wypełnili kwestionariusz Family Quality of Life Survey-2006 (FQOLS-2006), który pozwala na ocenę jakości życia rodzin w 9 obszarach życia: Zdrowie rodziny, Sytuacja finansowa, Relacje rodzinne, Wsparcie innych osób, Wsparcie w ramach specjalistycznych usług, System wartości, Kariera zawodowa i przygotowanie do kariery, Czas wolny i rekreacja, Interakcje społeczne.

Wyniki: Otrzymane wyniki wskazują na wyższą - na poziomie tendencji statystycznej - jakość życia ogółem rodzin z dzieckiem z APD w porównaniu do jakości życia rodzin z dziećmi z różnymi niepełnosprawnościami (oprócz głuchoty), lecz podobną do jakości życia rodzin z małymi dziećmi głuchymi. Badane rodziny z dzieckiem z APD najwyższą jakość życia przypisały obszarom: Relacje rodzinne, Zdrowie rodziny oraz Kariera zawodowa. Najniższe oceny jakości życia otrzymano w obszarach: Wsparcie w ramach specjalistycznych usług, Wparcie innych osób oraz Interakcje społeczne. Wśród usług specjalistycznych, z jakich korzystają rodziny z dzieckiem z APD, przeważa opieka medyczna świadczona przez lekarzy różnych specjalności (54\%), w tym lekarzy psychiatrów (20\%), na kolejnym miejscu plasują się: terapia logopedyczna (47\%) oraz terapia psychologiczna wraz z poradnictwem psychologicznym i psychoterapią dla rodziców/rodzin (44\%). Wnioski: Wyniki badania pozwalają na stwierdzenie, że dotychczasowe usługi specjalistyczne oferowane dzieciom z APD i ich rodzinom są niewystarczające względem istniejących potrzeb dzieci z APD oraz ich rodzin. Obszar ten z pewnością wymaga dalszych badań. FCA stwarza szansę na zmianę istniejącej sytuacji rodzin z dzieckiem z APD.

Słowa kluczowe: jakość życia rodziny • FQOLS-2006 • zaburzenia przetwarzania słuchowego (APD) • dziecko z APD • wsparcie społeczne • wsparcie w ramach specjalistycznych usług

\begin{abstract}
Introduction: According to the Family Centered Approach (FCA), the family plays a leading role in supporting a child's development, rehabilitation, and treatment. A family's quality of life becomes an interdisciplinary diagnostic target as well as the aim of the intervention. So far, there have been no studies on the quality of life of families with children with central auditory processing disorders (APD). The study investigates the problem of the quality of life of families with a child with APD, particularly in terms of specialist support and social support. This study aimed to compare the quality of life of families with a child with APD to the quality of life of families with a child with different impairments.
\end{abstract}

Adres autora: Joanna Kobosko, Zakład Audiologii Eksperymentalnej, Instytut Fizjologii i Patologii Słuchu, ul. Mochnackiego 10, 02-042, Warszawa, e-mail: j.kobosko@ifps.org.pl 
Material and methods: The study involved 38 families with children with ADP aged on average 9.8 years. Parents filled in the Family Quality of Life Survey-2006 (FQOLS-2006). FQOLS-2006 assesses the quality of life of a family in several aspects: Health of the family, Financial well-being, Family relationships, Support from others, Support from disability-related services, Influence of values, Careers and preparing for careers, Leisure and recreation, Community interactions.

Results: The results obtained in this study show higher, on the level of statistical trend, quality of life of families with children with APD compared to families of children with different impairments (excluding deafness). It was similar to the quality of life of families with small deaf children. Studied families with APD have scored the highest quality of life in the domains Family relationships, Health of the family, and Careers and preparing for careers. The lowest scores in the quality of life were in the domains Support from disability-related services, Support from others, and Community interactions. Among the specialist services used by families of children with APD dominates medical care provided by physicians of different specialties (54\%), including psychiatrist (20\%), then speech and language therapy (47\%), psychological therapy including psychological counseling and psychotherapy for parents/families (44\%).

Conclusions: We can infer that the present offer of services for children with APD and their families is insufficient in terms of their needs. The FCA creates a chance to change the current situation of families with children with APD in this regard.

Key words: family quality of life • FQOLS-2006 • auditory processing disorders (APD) • APD child • social support • support from specialist services

\begin{tabular}{|c|c|c|}
\hline Skrót & Rozwinięcie skrótu & Odpowiednik w języku polskim \\
\hline ADHD & Attention-Deficit Hyperactivity Disorder & zespół nadpobudliwości psychoruchowej z deficytem uwagi \\
\hline APD & Auditory Processing Disorders & zaburzenia przetwarzania słuchowego \\
\hline ASD & Autism Spectrum Disorder & spektrum zaburzeń autystycznych \\
\hline ASHA & $\begin{array}{c}\text { American Speech-Language-Hearing } \\
\text { Association }\end{array}$ & Amerykańskie Stowarzyszenie Mowy, Języka i Słuchu \\
\hline BSA & British Society of Audiology & Brytyjskie Towarzystwo Audiologiczne \\
\hline DD & Developmental Delays & opóźnienia rozwojowe \\
\hline FCA & Family-Centered Approach & podejście skoncentrowane na rodzinie \\
\hline FPT & Frequency Pattern Test & test sekwencji częstotliwości \\
\hline FQoL & Family Quality of Life & jakość życia rodziny \\
\hline KORP & Karty Oceny Rozwoju Psychoruchowego & - \\
\hline PSS-10 & Perceived Stress Scale & Skala Odczuwanego Stresu (PSS-10) \\
\hline SI & Sensory Integration & integracja sensoryczna \\
\hline SLI & Specific Language Impairment & specyficzne zaburzenia językowe \\
\hline SPPS & $\begin{array}{l}\text { Stymulacja Polimodalna Percepcji } \\
\text { Sensorycznej }\end{array}$ & - \\
\hline SPR & Skala Postaw Rodzicielskich & - \\
\hline
\end{tabular}

\section{Wprowadzenie}

Badania nad jakością życia rodziny (ang. Family Quality of Life, FQoL) zazwyczaj są podejmowane wówczas, gdy u dziecka zostaje zdiagnozowana niepełnosprawność, przewlekła lub poważna choroba lub też występują inne problemy rozwojowe. Nie bez przyczyny w podejściu skoncentrowanym na rodzinie (ang. Family-Centered Approach, FCA), którego istotną cechą jest traktowanie rodziny jako całości, upatruje się optymalnego rozwiązania sytuacji dziecka z niepełnosprawnością i jego rodziny. Jak wynika z opublikowanego przeglądu piśmiennictwa na ten temat [1], w wielu krajach FCA jest obecne w opiece zdrowotnej, różnego rodzaju usługach terapeutycznych/rehabilitacyjnych, wczesnej interwencji i wczesnej edukacji, edukacji specjalnej i powszechnej. O istocie tego podejścia stanowią jego następujące właściwości: zaangażowanie rodziców w podejmowanie decyzji dotyczących dziecka/rodziny, współpraca i partnerstwo, wzajemny szacunek (rodzica i terapeuty/ specjalisty), koncentracja na mocnych stronach rodziny/sytuacji, zindywidualizowane i elastyczne świadczenie usług, dzielenie się informacjami (ang. sharing), upodmiotowienie. Stwierdzono, że wykorzystanie podejścia skoncentrowanego na rodzinie sprzyja efektywności opieki zdrowotnej i zwiększa satysfakcję rodzin ze świadczonych usług [1,2], natomiast organizacja usług skoncentrowanych na rodzinie należy do dobrych praktyk (ang. best practices) służących optymalnemu rozwojowi dziecka [3]. 
Wśród koncepcji dotyczących jakości życia rodziny najbardziej rozpowszechniony jest integracyjny i wielowymiarowy model zaproponowany pod koniec lat 90. XX w. przez badaczy z Kanady - Ivana Browna i wsp. [4-6]. Ich zdaniem: „Jakość życia rodziny dotyczy stopnia, w jakim jednostki doświadczają własnej jakości życia w kontekście rodzinnym, a także tego, w jaki sposób rodzina jako całość ma możliwości wykorzystania swoich ważnych zasobów/możliwości i osiągnięcia swoich celów w społeczności i społeczeństwie, którego jest częścią" [4]. W wyniku prac nad teoretyczną podbudową FQoL oprócz opracowania konceptualizacji tego pojęcia powstało też narzędzie do oceny jakości życia rodzin: Family Quality of Life Survey-2006 (FQOLS-2006) [7], w którym uwzględniono 9 dziedzin życia rodziny: Zdrowie rodziny ${ }^{1}$, Sytuacja finansowa, Relacje rodzinne, Wsparcie innych osób, Wsparcie $w$ ramach specjalistycznych usług, System wartości, Kariera zawodowa i przygotowanie do kariery, Czas wolny i rekreacja, Interakcje społeczne, oraz 6 wymiarów, w jakich jakość życia rodziny w każdej z dziedzin jest oceniana: Znaczenie, Szanse ${ }^{2}$, Inicjatywa, Osiagnięcia, Stabilizacja i Satysfakcja.

W późniejszych latach podejście identyfikujące sfery czy obszary życia rodzin podlegające ocenie/pomiarowi pod względem ich jakości uzyskało miano „funkcjonalnego" [8]. Efektem opracowania narzędzia FQOLS-2006 są badania nad jakością życia rodzin z dziećmi z różnymi niepełnosprawnościami i schorzeniami prowadzone w różnych krajach, w tym m.in. Kanadzie, Australii, Izraelu [5,6,9], a także w Polsce $[6,10,11]$. Podsumowując ich wyniki, można powiedzieć, że jakość życia rodzin $\mathrm{z}$ dziećmi $\mathrm{z}$ różnymi niepełnosprawnościami i zaburzeniami neurorozwojowymi ma charakterystyczny wzorzec, na który składają się podobne oceny wybranych dziedzin życia rodzin dokonywane przez ich członków, głównie matki. Najwyższe $\mathrm{z}$ nich dotyczą dziedzin takich jak: Relacje rodzinne, Zdrowie rodziny oraz Wsparcie $w$ ramach specjalistycznych usług, najniższe wiążą się zaś ze wsparciem społecznym otrzymywanym przez rodziny od innych osób i Interakcjami społecznymi w lokalnej społeczności [6,9-11].

Im lepsza jakość funkcjonowania danej rodziny jako całości, wyrażana np. jakością relacji między małżonkami [12] czy funkcjonowaniem systemu rodzinnego [13], tym większa szansa na to, że rodzina poradzi sobie $\mathrm{z}$ zaistniałymi problemami, np. zaburzeniami przejawianymi przez dziecko, do jakich należą m.in. (centralne) zaburzenia przetwarzania słuchowego (ang. Auditory Processing Disorders, APD). Istotne w takiej sytuacji jest znalezienie i skorzystanie z różnych źródeł i form wsparcia, zarówno specjalistycznego (medycznego, psychologicznego czy rehabilitacyjnego), jak i wsparcia społecznego - poczynając od najbliższej rodziny, poprzez dalszą rodzinę, przyjaciół i znajomych, po szeroko rozumiane otoczenie społeczne.

\footnotetext{
W artykule w odniesieniu do pojęć reprezentujących 9 dziedzin życia rodziny oraz ich 6 wymiarów, które jednocześnie są oceniane za pomocą FQOLS-2006, zastosowano pisownię wielką literą oraz kursywę.

2 Wymiar Szanse w pierwotnej polskiej wersji kwestionariusza FQOLS-2006 został przetłumaczony jako Możliwości [6].
}

\section{Dzieci $\mathrm{z}$ centralnymi zaburzeniami przetwarzania słuchowego}

W ostatnim ćwierćwieczu w piśmiennictwie zarówno polskim, jak i zagranicznym pojawiły się stosunkowo liczne publikacje naukowe na temat trudności związanych z (centralnymi) zaburzeniami procesów przetwarzania słuchowego (APD) u dzieci, których słuch obwodowy jest w normie, i proponowanych metod terapii. Zgodnie $z$ kryteriami ASHA zdiagnozowanie APD możliwe jest między 6 a 7 rokiem życia [14]. APD znacznie częściej występuje u chłopców niż u dziewczynek [15]. Katz [16,17] opisał te zaburzenia jako niemożność pełnego wykorzystania słyszanego sygnału akustycznego przy prawidłowym jego odbiorze w strukturach obwodowych. Z kolei Brytyjskie Towarzystwo Audiologiczne (British Society of Audiology, BSA) podkreśla, że zaburzenia przetwarzania słuchowego wynikają z nieprawidłowej czynności mózgu charakteryzującej się niewłaściwym rozróżnianiem, separacją, grupowaniem, lokalizacją i porządkowaniem bodźców [17,18].

Różni autorzy zwracają uwagę, że zaburzenia procesów przetwarzania słuchowego skutkują u dzieci trudnościami w codziennym funkcjonowaniu, takimi jak problemy z: rozumieniem mowy w hałasie, rozumieniem mowy zniekształconej, rozumieniem dłuższych wypowiedzi, pytań i instrukcji podawanych ustnie; dzieci z APD mają trudności z uczeniem się ze słuchu, a także robieniem notatek ze słuchu, często dopytują, proszą o powtórzenie informacji, nieraz mają trudności z opanowaniem czytania, pisania, wypadają słabiej w testach i sprawdzianach wymagających polegania w przeważającym stopniu na analizatorze słuchowym. U niektórych dzieci mogą też występować trudności ze zrozumieniem mowy wynikające ze zmian prozodycznych [14,17-19].

Reasumując, trudności, jakich doświadczają dzieci z APD, wiążą się z funkcjonowaniem słuchowym; obserwowany jest negatywny ich wpływ ujawniający się w aktywności skoncentrowanej na zadaniu (ang. task-oriented), w którą zaangażowane są: procesy pamięci, uwagi, językowe oraz czytanie [20]. Zaburzenia APD mogą współwystępować z zaburzeniami neurorozwojowymi takimi jak: dysleksja, ADHD, SLI, DD, ASD [20,21], zaburzeniami rozwoju mowy, języka i /lub artykulacji [18], zaburzeniami emocjonalno-społecznymi oraz trudnościami szkolnymi [22-24].

Rozwój psychoruchowy dzieci z APD jest przedmiotem nielicznych wciąż badań. Badania wstępne nad siedmiolatkami ze zdiagnozowanymi APD (lecz z wykluczeniem innych zaburzeń neurorozwojowych $\mathrm{w}$ momencie prowadzenia badań, takich jak: dysleksja, ADHD, SLI, DD, ASD) zostały przeprowadzone przez Małgorzatę Ganc [25] z wykorzystaniem Kart Oceny Rozwoju Psychoruchowego (KORP) [26]. Uzyskane wyniki wskazują na niski poziom funkcjonowania w wielu sferach badanych dzieci. W zakresie rozwoju ruchowego i motoryki precyzyjnej niskie wyniki uzyskało odpowiednio 47\% i 52\% dzieci, w zakresie komunikacji i mowy 57\%, w obszarze wiedzy i uczenia się 38\%. Rozwój funkcji behawioralnych u ponad $40 \%$ badanych dzieci znajdował się na niskim poziomie w porównaniu do grupy normatywnej, a spostrzeganie wzrokowe i lateralizację na poziomie niskim 
stwierdzono u co 3. dziecka. Natomiast niski poziom rozwoju emocjonalno-społecznego w odniesieniu do grupy dzieci o typowym rozwoju wykazało $14 \%$ badanych dzieci 7-letnich.

Problemy emocjonalno-społeczne u dzieci z APD w wieku szkolnym (od 7 do 14 lat), jak wynika z naszych innych badań, występują w znacząco większym nasileniu niż u rówieśników o typowym rozwoju, dotyczy to zwłaszcza sfery nadaktywności i koncentracji uwagi, emocji oraz kontaktów z rówieśnikami [22]. Z kolei z badań przeprowadzonych w Niemczech [27] wynika, że dziewczęta z APD w wieku od 12 do 15 lat doświadczają większego stresu niż chłopcy z APD w podobnym wieku. Ponadto, niezależnie od płci, odczuwany poziom stresu był wyższy w przypadku sytuacji społecznych, takich jak np. „kłótnia z kolegą" czy „problemy z pracą domową", niż w przypadku sytuacji związanych z trudnościami wynikającymi z APD, jak np. „rozumienie nie do końca, o czym inni mówią lub z czego się śmieją" czy „pytania po kilka razy z powodu nierozumienia czegoś, co mówią inni”.

\section{Rodzina/rodzice dziecka $\mathrm{z}$ centralnymi zaburzeniami przetwarzania słuchowego - perspektywa psychologiczna}

W kontekście dzieci z APD i ich problemów powstaje pytanie o psychologiczne funkcjonowanie rodziców, a szerzej - o jakość życia rodzin wychowujących dzieci z tymi zaburzeniami. Z badań wynika, że odczuwany przez matki dzieci z APD ogólny stres (mierzony Skala Odczuwanego Stresu, PSS-10) ma przeciętne nasilenie. Natomiast niższy poziom tego stresu odczuwają w przeprowadzonych badaniach matki z takimi cechami osobowości, jak (wyższa) stabilność emocjonalna i ekstrawersja [28]. Z kolei postawy rodzicielskie (mierzone Skala Postaw Rodzicielskich, SPR) rodziców dzieci z APD (w wieku od 6 do 17 lat) - w porównaniu do postaw rodziców dzieci z populacji ogólnej rozwijających się typowo - charakteryzują się: nieco mniejszą akceptacją, zwiększonymi wymaganiami, jak i ochranianiem, mniejszym przyzwoleniem na autonomię, a także zdecydowanie wyższą niekonsekwencją względem dziecka [29].

Interesującym wynikiem są istotne różnice występujące między matkami i ojcami w nasileniu postaw rodzicielskich w grupie rodziców dzieci z APD [30], obserwowane także w populacji ogólnej rodziców i ich dzieci [31]. $\mathrm{W}$ porównaniu z ojcami matki charakteryzowała postawa większej akceptacji, jak i ochraniania dziecka z APD, natomiast $\mathrm{w}$ odniesieniu do pozostałych badanych postaw nie stwierdzono istotnych różnic [30].

Z postawami rodzicielskimi pozostaje w związku efektywność terapii pn. Stymulacja Polimodalna Percepcji Sensorycznej Skarżyńskiego (SPPS) - jednej z metod proponowanych dzieciom z zaburzeniami koncentracji uwagi słuchowej [30,32]. Dla przykładu, dzieci z APD, których matki były w stopniu wysokim niekonsekwentne wobec dziecka, osiągały mniejszą skuteczność terapii SPPS w zakresie poprawy w Teście Sekwencji Częstotliwości (Frequency Pattern Test, FPT) mierzonej po terapii w porównaniu $\mathrm{z}$ wynikiem przed jej zastosowaniem [30]. Jednak dotąd nie badano jakości życia rodzin z dzieckiem z APD ocenianej w ujęciu funkcjonalnym $\mathrm{z}$ wykorzystaniem narzędzia FQOLS-2006.

\section{Cel pracy}

Celem pracy jest ocena jakości życia rodzin z dzieckiem z APD za pomocą kwestionariusza FQOL-2006. Ponadto postawiono pytanie, czy w badanych rodzinach różni się ona od jakości życia rodzin z dziećmi z innymi niepełnosprawnościami (badania przeprowadzone przez Dorotę Otapowicz, Agnieszkę Sakowicz-Boboryko i Dorotę Wyrzykowską-Koda [10]) oraz jakości życia rodzin z małymi dziećmi głuchymi (badania przeprowadzone przez Joannę Kobosko i wsp. [11]). Dodatkowo celem pracy było przyjrzenie się wsparciu społecznemu, w tym specjalistycznemu, jakie otrzymują rodziny z dzieckiem z APD, a co za tym idzie - analiza jakościowa (FQOL-2006/część A) trzech dziedzin jakości życia rodzin: Wsparcie innych osób, Wsparcie $w$ ramach specjalistycznych usług oraz Interakcje społeczne, które to sfery uzyskały w przeprowadzonych badaniach najniższe oceny rodziców z dzieckiem z APD.

\section{Materiał i metody}

\section{Uczestnicy badań}

W badaniach uczestniczyło 38 rodziców dzieci z APD (30 matek, 8 ojców) w wieku od 30 do 48 lat (średnio 39,6 lat). Wykształcenie wyższe miało $23(60,5 \%)$ rodziców, niepełne wyższe (pomaturalne lub licencjackie) 3 (7,9\%), a średnie $12(31,6 \%)$ osób. W związku małżeńskim pozostawało $27(71,1 \%)$ badanych rodziców, a w związku nieformalnym 3 (7,9\%). Status rozwiedzionych miało $6(15,8 \%)$ rodziców, a $1(2,6 \%)$ matka była wdową.

Grupę dzieci z APD stanowiło 28 chłopców i 10 dziewczynek, w wieku od 7 do 13 lat i 5 miesięcy (średnio 9 lat i 10 miesięcy). Zaburzenia APD były zdiagnozowane zgodnie z kryteriami ASHA [14] i obowiązującymi procedurami [33]. U badanych dzieci nie występowały zaburzenia takie jak: dysleksja, ADHD, DD, SLI, ASD. Ocena audiometryczna wykazała, że u badanych dzieci słuch obwodowy jest w normie (dzieci nie korzystały z aparatów słuchowych). Zaburzenia w rozwoju mowy w tej grupie (lecz niezdiagnozowane jako SLI) zgłaszało $28(73,7 \%)$ rodziców, a u 10 (26,3\%) dzieci mowa rozwijała się prawidłowo. Zaburzenia artykulacji występowały u 31 (81,6\%) dzieci, natomiast u $7(18,4 \%)$ wymowa była prawidłowa. Według informacji od rodziców zawartych w ankiecie informacyjnej inne problemy zdrowotne, takie jak: alergie, astma, choroba lokomocyjna, torbiel szyszynki i in., obecne były u $18(47,4 \%)$ dzieci. We wszystkich badanych rodzinach dzieci z APD miały rodzeństwa - od 1 do 4 (średnio 2,16).

\section{Narzędzia badawcze}

W badaniach wykorzystano kwestionariusz Jakość Życia Rodziny (Family Quality of Life Survey, FQOLS-2006) oraz ankietę informacyjną. FQOLS-2006 stworzył Ivan Brown z zespołem [6,7]. Polska wersja tego kwestionariusza, której autorkami są: Ewa Zasępa, Ewa Wapiennik i Agnieszka Wołowicz (2010) [6], po raz pierwszy została wykorzystana do badań nad rodzinami dzieci z niepełnosprawnością intelektualną $[6,34]$. 
Na podstawie FQOLS-2006 oceniono 9 dziedzin życia rodziny, do których należą: Zdrowie rodziny, Sytuacja finansowa, Relacje rodzinne, Wsparcie innych osób, Wsparcie $w$ ramach specjalistycznych usług, System wartości, Kariera zawodowa i przygotowanie do kariery, Czas wolny i rekreacja, Interakcje społeczne. FQOLS-2006 składa się z części A i B. Część A obejmuje ocenę obiektywną jakości życia rodziny (zarówno ilościową, jak i jakościową), natomiast część B pozwala na oszacowanie subiektywnej oceny każdej dziedziny życia na 5-stopniowej skali typu Likerta w następujących wymiarach: Znaczenie, Szanse, Inicjatywa, Osiagnięcia, Stabilność, Satysfakcja. Skala wyników ocenianych dziedzin życia rodziny, jak i ich 6 wymiarów mieści się w zakresie od 1 do 5 punktów. Dla każdej dziedziny i jej wymiarów obliczane są średnie dokonanych ocen, a następnie wynik ogólny jakości życia rodziny, będący z kolei średnią ocen ze wszystkich dziedzin życia. W dalszych analizach otrzymanych rezultatów uwzględnione zostały wyniki części A kwestionariusza FQOLS-2006 w odniesieniu do trzech dziedzin życia rodzin (Wsparcie innych osób, Wsparcie w ramach specjalistycznych usług, Interakcje społeczne) oraz wyniki części B.

W ramach wstępnego oszacowania psychometrycznego polskiej wersji FQOLS-2006 dla poszczególnych dziedzin jakości życia rodzin współczynnik alpha Cronbacha wyniósł od 0,44 (Zdrowie rodziny) do 0,85 (Czas wolny i rekreacja), przy czym większość uzyskała wartości powyżej 0,7 [6].

Z kolei ankieta informacyjna obejmowała pytania dotyczące informacji socjodemograficznych w odniesieniu do dziecka (płeć, wiek) i rodzica (wiek, wykształcenie, status małżeński/partnerski, liczba dzieci), a także danych związanych z innymi niż APD problemami zdrowotnymi dziecka.

\section{Procedura badań}

Kwestionariusz FQOLS-2006 oraz ankietę informacyjną wypełniali rodzice (matka lub ojciec) podczas hospitalizacji dzieci w Instytucie Fizjologii i Patologii Słuchu. Wyniki części B kwestionariusza FQOLS-2006 zostały porównane (test $\mathrm{t}, \mathrm{p}<0,05$ ) do wyników uzyskanych za pomocą tego samego narzędzia $w$ badaniach rodzin dzieci $z$ niepełnosprawnościami innymi niż głuchota (Otapowicz i wsp. 2016) [10], a także do wyników badań nad rodzinami z małymi dziećmi głuchymi (Kobosko i wsp. 2020) [11]. W badaniach tych oceny jakości życia rodzin dokonywały wyłącznie matki. W odniesieniu do rodzin z dzieckiem z APD analizie jakościowo-ilościowej zostały poddane trzy dziedziny życia rodzin: Wsparcie innych osób, Wsparcie w ramach specjalistycznych usług, Interakcje społeczne.

\section{Wyniki}

Poniżej zaprezentowano dane ilościowe (FQOLS-2006/ część B) oraz dane jakościowo-ilościowe w 3 dziedzinach życia rodzin $\mathrm{z}$ dzieckiem $\mathrm{z}$ APD o najniższych ocenach, a mianowicie: Wsparcie innych osób (FQOLS-2006/ IV/część A), Wsparcie $w$ ramach specjalistycznych usług (FQOLS-2006/V/część A) oraz Interakcje społeczne (FQOLS-2006/IX /część A).

\section{Jakość życia rodzin z dzieckiem z APD}

Najwyżej ocenionymi przez rodziców dziedzinami życia rodziny są: Relacje rodzinne, a następnie Zdrowie

Tabela 1. Jakość życia rodzin z dzieckiem z APD - porównanie wyników ( $M$ - średnia; $S D$ - odchylenie standardowe; $p$ - poziom istotności) z jakością życia rodzin małych dzieci głuchych [11] i rodzin dzieci z innymi niepełnosprawnościami [10] w wyodrębnionych dziedzinach i ogólnej jakości życia (FQOLS-2006/część B).

Table 1. The quality of life of families with APD children - comparison of the results ( $M$ - mean value; $S D$ - standard deviation; $p$ - significance level) with the quality of life of families with young deaf children [11] and families with children with other disabilities [10] in selected domains and overall quality of life (FQOLS-2006/part B).

\begin{tabular}{|c|c|c|c|}
\hline Dziedzina jakości życia (FQoLS-2006) & $\begin{array}{l}\text { Rodzina z dzieckiem } \\
\qquad \begin{array}{l}\text { z APD } \\
(n=38) \text { M (SD) }\end{array}\end{array}$ & $\begin{array}{l}\text { Rodzina z dzieckiem } \\
\text { głuchym }{ }^{1} \\
(n=50) M(S D)\end{array}$ & $\begin{array}{l}\text { Rodzina z dzieckiem } \\
\text { niepełnosprawnym² } \\
(n=31) \mathrm{M}(\mathrm{SD})\end{array}$ \\
\hline Zdrowie rodziny & $3,73(0,61)$ & $3,72(0,89)$ & $3,19(0,91)^{* *}$ \\
\hline Sytuacja finansowa & $3,53(0,47)$ & $3,53(0,76)$ & $3,27(0,88)$ \\
\hline Relacje rodzinne & $3,94(0,47)$ & $3,97(0,74)$ & $3,16(0,95)^{* * *}$ \\
\hline Wsparcie innych osób & $3,22(0,20)$ & $3,21(0,76)$ & $2,82(0,78)^{* *}$ \\
\hline Wsparcie w ramach specjalistycznych usług & $3,31(0,38)$ & $3,70(0,81)^{* *}$ & $3,52(1,08)$ \\
\hline System wartości & $3,34(0,27)$ & $3,36(0,85)$ & $2,55(1,45)^{* * *}$ \\
\hline Kariera zawodowa członków rodziny & $3,71(0,29)$ & $3,36(0,99)^{*}$ & $3,22(0,86)^{* *}$ \\
\hline Czas wolny i rekreacja & $3,46(0,31)$ & $3,56(0,77)$ & $3,16(0,71)$ \\
\hline Interakcje społeczne & $3,22(0,24)$ & $3,22(0,81)$ & $3,01(0,71)^{\#}$ \\
\hline Wynik ogólny jakości życia (QOL ogółem) & $3,47(0,56)$ & $3,51(0,82)$ & $3,1(1,02)^{\#}$ \\
\hline \multicolumn{4}{|c|}{$\begin{array}{l}{ }^{1} \text { Dane z badań opublikowanych w artykule: J. Kobosko, M. Ganc, P. Paluch, W.W. Jędrzejczak, A. Geremek-Samsonowicz, } \\
\text { H. Skarżyński (2020) [11]. } \\
{ }^{2} \text { Dane z badań opublikowanych w artykule: D. Otapowicz, A. Sakowicz-Boboryko, D. Wyrzykowska-Koda (2016) [10]. M - średnia; } \\
\text { SD - odchylenie standardowe; } p \text { - poziom istotności statystycznej: }{ }^{*} p<0,1 ;^{*} p<0,05{ }^{* *} p<0,01 ;^{* * *} p<0,001 .\end{array}$} \\
\hline
\end{tabular}


5

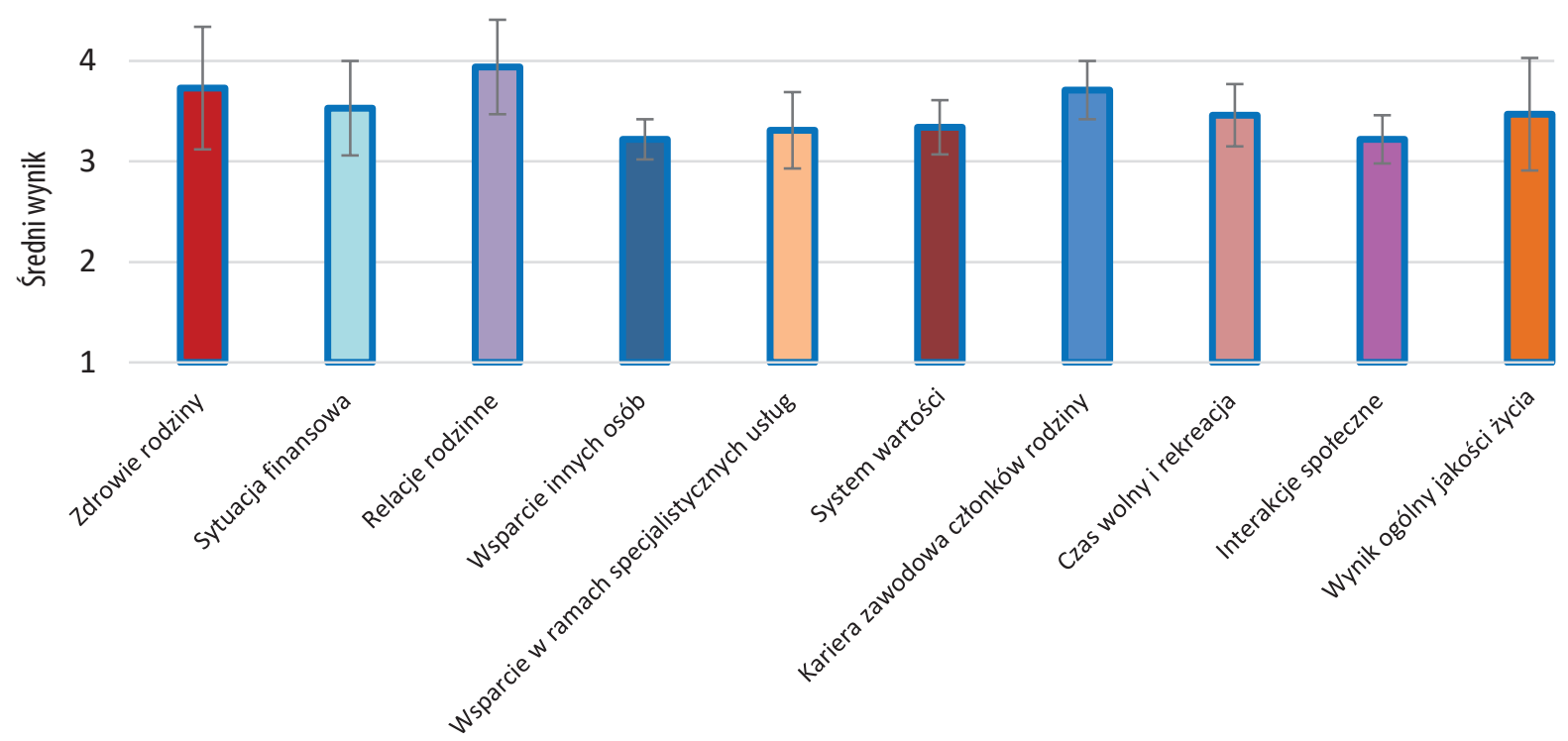

Dziedziny jakości życia rodziny (FQ0LS-2006)

Rycina 1. Jakość życia rodzin z dzieckiem z APD w wyodrębnionych dziedzinach i ogólna jakość życia (FQOLS-2006) (średnia, odchylenie standardowe).

Figure 1. The quality of life of families with APD children in the selected domains and general quality of life (FQOLS-2006) (mean values and standard deviation).

Tabela 2. Jakość życia rodzin z dzieckiem z APD w wyodrębnionych dziedzinach i ogólna jakość życia (FQOLS-2006/część B) z uwzględnieniem wymiarów oceny każdej dziedziny: Znaczenie, Szanse, Inicjatywa, Osiągnięcia, Stabilizacja, Satysfakcja (M - średnia; SD - odchylenie standardowe).

Table 2. The quality of life of families with APD children in selected domains and general quality of life (FQOLS-2006/part B) when taking into account dimensions in each domain: Importance, Opportunities, Initiative, Attainment, Stability, Satisfaction ( $M$ - mean value; $S D$ - standard deviation).

\begin{tabular}{|c|c|c|c|c|c|c|}
\hline $\begin{array}{l}\text { Dziedzina } \\
\text { jakości życia } \\
\text { (FQoLS-2006) }\end{array}$ & 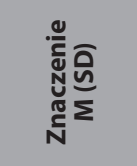 & 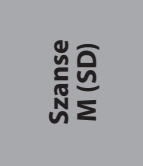 & 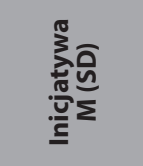 & 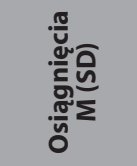 & 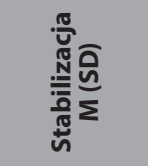 & 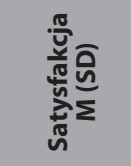 \\
\hline Zdrowie rodziny & $4,95(0,23)$ & $3,36(1,29)$ & $3,46(0,85)$ & $3,61(0,63)$ & $3,37(0,59)$ & $3,66(0,78)$ \\
\hline Sytuacja finansowa & $4,18(0,56)$ & $2,92(1,05)$ & $3,89(0,65)$ & $3,53(0,65)$ & $3,13(0,66)$ & $3,53(0,65)$ \\
\hline Relacje rodzinne & $4,60(0,55)$ & $4,03(0,59)$ & $3,97(0,59)$ & $4,05(0,61)$ & $3,13(0,41)$ & $3,84(0,79)$ \\
\hline Wsparcie innych osób & $3,6(0,97)$ & $3,42(0,92)$ & $2,81(0,95)$ & $2,81(1,06)$ & $3,00(0,57)$ & $3,66(0,63)$ \\
\hline $\begin{array}{l}\text { Wsparcie w ramach } \\
\text { specjalistycznych usług }\end{array}$ & $3,94(0,69)$ & $3(1,39)$ & $3,42(1)$ & $3(0,96)$ & $3,03(0,28)$ & $3,47(0,6)$ \\
\hline System wartości & $3,73(0,93)$ & $3,32(1,16)$ & $3(0,91)$ & $3,13(1)$ & $3,3(0,64)$ & $3,57(0,73)$ \\
\hline $\begin{array}{l}\text { Kariera zawodowa } \\
\text { członków rodziny }\end{array}$ & $4,13(0,81)$ & $3,72(0,92)$ & $3,63(1,05)$ & $3,71(0,96)$ & $3,24(0,75)$ & $3,81(0,65)$ \\
\hline Czas wolny i rekreacja & $4,05(0,77)$ & $3,39(0,98)$ & $3,34(0,81)$ & $3,26(0,83)$ & $3,18(0,46)$ & $3,55(0,76)$ \\
\hline Interakcje społeczne & $3,76(0,91)$ & $3,23(0,89)$ & $2,87(0,74)$ & $2,81(0,77)$ & $3,08(0,27)$ & $3,58(0,6)$ \\
\hline $\begin{array}{l}\text { Ogółem } \\
\text { (wszystkie dziedziny } \\
\text { - średnia ocen dziedzin) }\end{array}$ & $\begin{array}{c}4,1 \\
(0,43)\end{array}$ & $\begin{array}{c}3,38 \\
(0,34)\end{array}$ & $\begin{array}{c}3,38 \\
(0,42)\end{array}$ & $\begin{array}{c}3,32 \\
(0,43)\end{array}$ & $\begin{array}{l}3,16 \\
(0,12)\end{array}$ & $\begin{array}{l}3,63 \\
(0,12)\end{array}$ \\
\hline
\end{tabular}


Wsparcie praktyczne (\%)

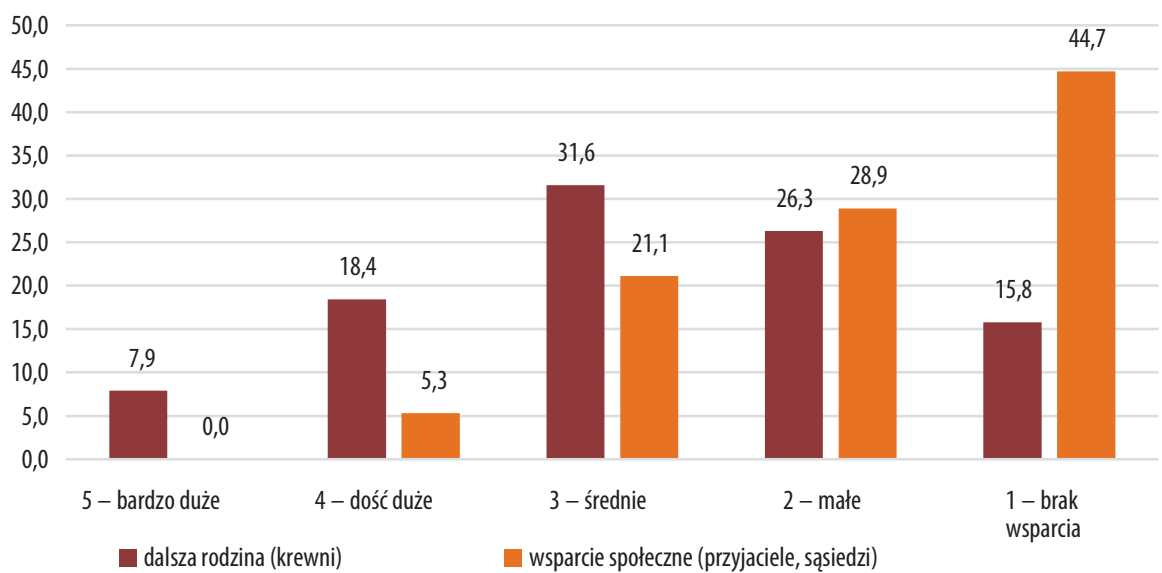

Rycina 2. Wsparcie praktyczne udzielane rodzinom z dzieckiem z APD przez dalszą rodzinę (krewni) oraz otoczenie społeczne (sąsiedzi, przyjaciele): 5 - bardzo duże, 4 - dość duże, 3 - średnie, 2 - małe, 1 - brak wsparcia (FQOLS-2006/IV - część A. 1a, 3a).

Figure 2. Practical support provided to families with a child with APD by further family (relatives) and social environment (neighbors, friends): 5 - very large, 4 - rather large, 3 - middle, 2 - small, 1 - no support (FQOLS-2006/IV - part A. 1a, 3a). rodziny i Kariera zawodowa, najniższe oceny przypisano zaś dziedzinom: Wsparcie innych osób, Interakcje społeczne oraz Wsparcie w ramach specjalistycznych usług. Ogólna jakość życia rodzin z dzieckiem z APD jest podobna do uzyskanej w badaniach nad rodzinami z małym dzieckiem głuchym [11], a na poziomie tendencji statystycznej - wyższa niż w rodzinach z dziećmi z innymi niepełnosprawnościami z wyjątkiem głuchoty [10]. Istotne różnice na korzyść jakości życia rodzin $\mathrm{z}$ dzieckiem $\mathrm{z}$ APD względem rodzin $\mathrm{z}$ dziećmi $\mathrm{z}$ innymi niepełnosprawnościami [10] stwierdzono w dziedzinach: Zdrowie rodziny, Relacje rodzinne, Wsparcie innych osób, System wartości, Kariera zawodowa członków rodziny, Interakcje społeczne (tendencja). Względem jakości życia rodzin z małym dzieckiem głuchym ocena jakości życia rodzin $\mathrm{z}$ dzieckiem $\mathrm{z}$ APD różni się jedynie $\mathrm{w}$ dwóch obszarach: Wsparcie $w$ ramach specjalistycznych usług (ocena niższa w rodzinach z dzieckiem z APD) oraz Kariera zawodowa członków rodzin (ocena wyższa w rodzinach $\mathrm{z}$ dzieckiem z APD). Jakość życia rodzin z dzieckiem z APD jest podobna we wszystkich porównywanych rodzinach $\mathrm{w}$ obszarach: Sytuacja finansowa rodzin oraz Czas wolny i rekreacja (tabela 1 , rycina 1 ).

Gdy przyjrzymy się wymiarom ocenianych dziedzin jakości życia rodzin z dzieckiem z APD (tabela 2), widzimy, że największe Znaczenie dla rodzin ma Zdrowie oraz Relacje rodzinne i Sytuacja finansowa wraz z Kariera zawodowa. W percepcji rodziców najmniejsze znaczenie ich rodziny przywiązują do Wsparcia innych osób. Rodzice dzieci z APD największych Szans dla rodziny upatrują w Relacjach rodzinnych i Karierze zawodowej. Natomiast w wymiarze Inicjatywy najwyższe oceny w ich podejmowaniu dotyczą Relacji rodzinnych, najniższe zostały zaś przypisane dziedzinom Wsparcie innych osób i Interakcje społeczne. Z kolei największe Osiagnięcia rodziny z dzieckiem z APD rodzice wiążą z Relacjami rodzinnymi, najmniejsze dotyczą zaś sfer Wsparcie innych osób i Interakcje społeczne. W wymiarze Stabilizacja najwyższą jakość przypisano dziedzinie Zdrowie rodziny, najniższa przypadła zaś dziedzinom: Wsparcie innych osób, Wsparcie $w$ ramach specjalistycznych ustug oraz Interakcje społeczne. Największą Satysfakcję rodzice z dzieckiem z APD czerpią z obszarów: Relacje rodzinne i Kariera zawodowa, najniższą zaś z obszaru: Wsparcie $w$ ramach specjalistycznych ustug.

\section{Jakość życia rodzin z dzieckiem z APD w wybranych dziedzinach: Wsparcie innych osób, Wsparcie w ramach specjalistycznych ustug oraz Interakcje społeczne - analiza jakościowo-ilościowa}

\section{Wsparcie innych osób}

Dziedzina ta należy do jednej z trzech najniżej ocenionych przez rodziców z dzieckiem z APD (tabela 1, rycina 1 ). Celem lepszego rozpoznania tego obszaru (FQOLS-2006/IV/ część A) w ocenie jakościowej bierze się pod uwagę: wsparcie praktyczne i wsparcie emocjonalne otrzymywane przez rodzinę od osób spoza najbliższej rodziny, a więc od krewnych (dalsza rodzina) oraz przyjaciól, sąsiadów i znajomych (otoczenie społeczne), oraz charakterystykę życia społecznego rodzin w wybranych aspektach.

Wsparcie praktyczne. Na ten rodzaj wsparcia składa się m.in. pomoc w opiece nad członkami rodziny, zakupach czy zajmowaniu się domem. Tę formę wsparcia od osób z dalszej rodziny zdaniem badanych rodziców otrzymuje: w stopniu od dużego do średniego $48 \%$ rodzin z dzieckiem z APD, w niewielkim stopniu 26\%, nie otrzymuje go wcale $16 \%$. Ze strony znajomych i przyjaciól wsparcie to otrzymuje w niewielkim stopniu niemal 30\% rodzin, brak takiego wsparcia relacjonuje prawie $50 \%$ rodziców (rycina 2). Z powyższych danych wynika, że jeśli wziąć pod uwagę osoby spoza najbliższej rodziny, to rodzice dziecka z APD mogą liczyć na praktyczne wsparcie raczej ze strony dalszych krewnych niż przyjaciół, znajomych czy sąsiadów.

Wsparcie emocjonalne. Ten rodzaj wsparcia, polegający m.in. na dodawaniu otuchy, słuchaniu i rozmawianiu, od dalszej rodziny otrzymuje (w zakresie od bardzo dużego do średniego) około $65 \%$ rodzin uczestniczących w badaniach, natomiast od przyjaciół i sąsiadów - $42 \%$ rodzin. Można więc powiedzieć, że źródłem emocjonalnego wsparcia są częściej osoby $\mathrm{z}$ dalszej rodziny niż z otoczenia społecznego (rycina 3 ). 


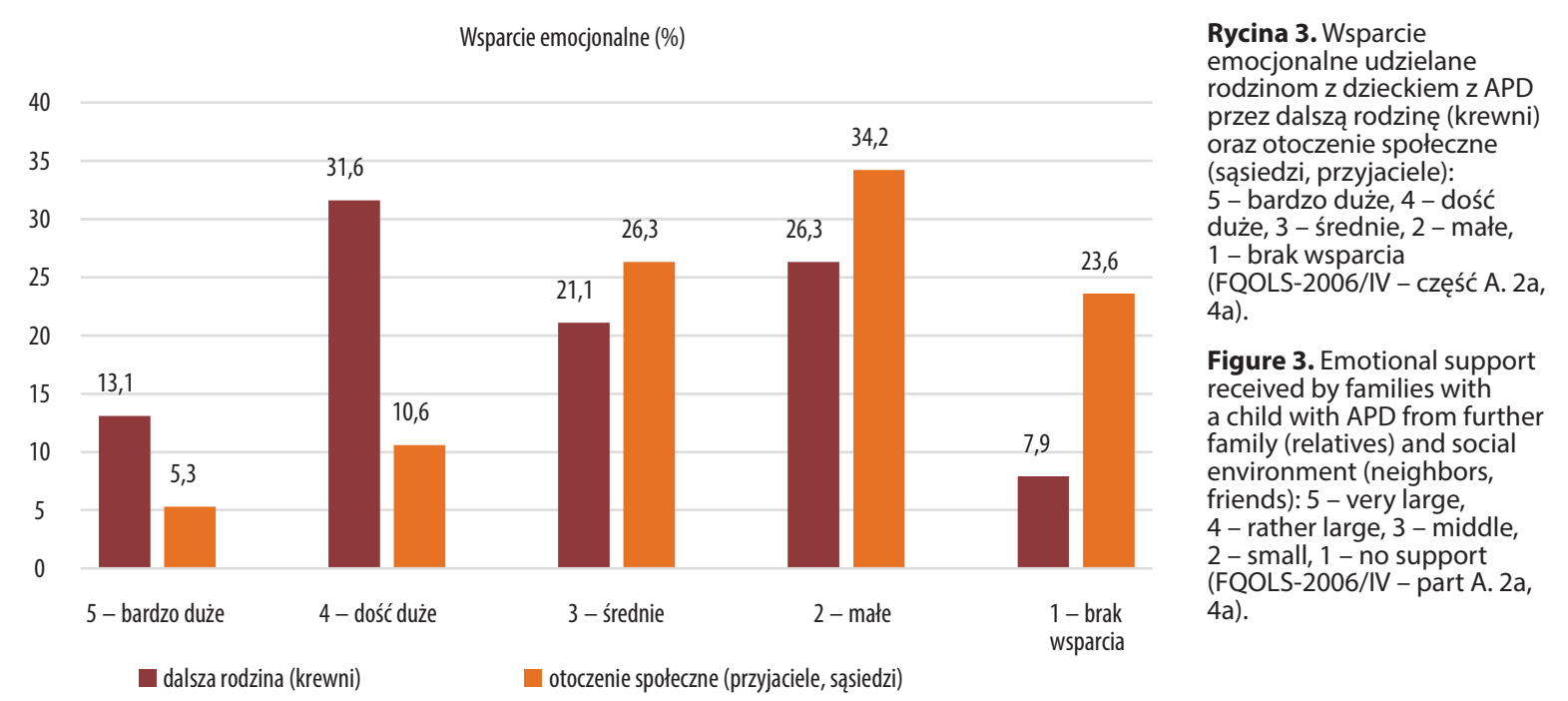

Życie społeczne poza rodziną w ocenie rodziców z dzieckiem z APD (\%)

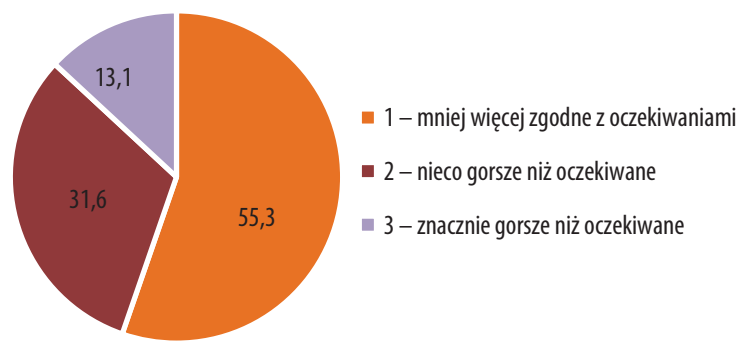

Życie społeczne rodziny. Rodzice dzieci z APD określili swoje życie społeczne jako „takie, jakie chcieliby, aby było” w 55\%. „Nieco gorsze” okazało się w przypadku 32\% rodzin, a za znacząco gorsze od oczekiwań uznało je $13 \%$ badanych rodziców (rycina 4). W uzasadnieniach rodziców dotyczących „nieco gorszej” lub „gorszej” oceny pojawiały się takie wypowiedzi jak: „Rzadziej niż chciałabym spotykam się z sąsiadami i znajomymi, sporadycznie idę do kina i teatru”; "Ciągłe zmęczenie ogranicza moje kontakty”; „Jako jedyny opiekun dzieci, czasami nie mam czasu na wyjścia”, „Nie ma życia społecznego poza rodziną, od wielu lat znajomi albo bez dzieci, albo daleko". Rodzice pozytywnie oceniający swoje życie społeczne piszą m.in.: „Mam dużo znajomych i przyjaciół, na których mogę polegać” czy „Mam dobre kontakty w pracy, a także w organizacjach, w których działam”.

Należy dodać, że rodzice dzieci z APD niezwykle rzadko udzielają odpowiedzi na pytania zawarte w części A i B FQOLS-2006 sformułowane w sposób otwarty i odnoszące się np. do dziedziny Wsparcie innych osób. Przykładem jest pozycja 7 (FQOLS-2006/IV - część B.7): „Prosimy podać, jeśli Pan/Pani zechce i uzna za stosowne, dodatkowe informacje i wyjaśnienia związane z otrzymywanym od innych osób wsparciem emocjonalnym i praktycznym", na którą odpowiedziało 3 rodziców. Z jednej wypowiedzi dowiedzieć się można, że „dziadkowie przyjęli
Rycina 4. Życie społeczne poza rodziną w ocenie rodziców z dzieckiem z APD: 1 - mniej więcej zgodne z oczekiwaniami, - nieco gorsze niż oczekiwane, 3 - znacznie gorsze niż oczekiwane (FQOLS-2006/IV - część A. 5a).

Figure 4. Social life outside of the family in the assessment of parents of a child with APD: 1 - consistent with expectations, 2 - somewhat worse than expected, 3 - significantly worse than expected (FQOLS-2006/IV - part A. 5a). wnuka na 3 miesiące przed maturą do siebie i opłacają korepetycje", z drugiej - o trudnej sytuacji matki biorącej udział w badaniach: „na co dzień nie mam nikogo bliskiego, ale jak jest potrzeba, dzieci zachorują, to przyjeżdża mama zaopiekować się nimi" - która na wsparcie społeczne od osób spoza najbliższej rodziny liczyć może w niewielkim stopniu lub wcale. W trzecim komentarzu znalazła się informacja, skąd badana rodzina czerpie wsparcie społeczne: „Mamy wąskie grono przyjaciół. Są to ludzie, którzy nas akceptują i rozumieją. Ważne jest, aby mieć choć jedną osobę, która nas słucha i wspiera, niż setki, które się uśmiechają. Najważniejsze jest wsparcie emocjonalne i to otrzymujemy".

Tak bardzo ograniczone dane uniemożliwiają przeprowadzenie pogłębionej analizy jakościowej życia rodzin z dzieckiem z APD w dziedzinie Wsparcia innych osób (a także w pozostałych dziedzinach życia rodziny). Pozostaje też kwestia przyczyny braku odpowiedzi w licznych pozycjach kwestionariusza sformułowanych $\mathrm{w}$ formie pytań otwartych. Z perspektywy psychologicznej możemy mówić m.in. o mechanizmach obronnych uruchamiających się u badanych rodziców w sytuacji zagrożenia (czyli w tym wypadku w konfrontacji z poruszanymi zagadnieniami), negatywnych emocjach, w różnym stopniu dostępnych refleksji. Mogą one uniemożliwiać werbalizację doświadczeń rodzica, a w konsekwencji - udzielenie odpowiedzi. 
Tabela 3. Usługi specjalistyczne, z jakich korzystają członkowie rodzin z dzieckiem z APD (FQOLS-2006/V - część A. 1.1-1.27). Table 3. Specialist services used by the families with a child with APD (FQOLS-2006/V - part A. 1.1-1.27).

\begin{tabular}{|c|c|c|}
\hline & Nazwa usługi & $\begin{array}{l}\text { Liczba rodzin z dzieckiem } \\
\text { z APD korzystających } \\
\text { z tej kategorii usług } \\
(n=38)\end{array}$ \\
\hline 1. & $\begin{array}{l}\text { Świadczenie pieniężne } \\
\text { Brak odpowiedzi - } 2 \text { (5,3\%) }\end{array}$ & $7(18,4 \%)$ \\
\hline 2. & $\begin{array}{l}\text { Praca socjalna /koordynacja usług } \\
\text { Brak odpowiedzi - } 2(5,3 \%)\end{array}$ & $0(0 \%)$ \\
\hline 3. & $\begin{array}{l}\text { Asystent wspierający (osobisty lub rodziny) } \\
\text { Brak odpowiedzi - } 2(5,3 \%)\end{array}$ & $0(0 \%)$ \\
\hline 4. & $\begin{array}{l}\text { Płatne usługi opiekuńcze/pielęgnacyjne } \\
\text { Brak odpowiedzi - } 2(5,3 \%)\end{array}$ & $2(5,3 \%)$ \\
\hline 5. & Opieka zastępcza & $0(0 \%)$ \\
\hline 6. & $\begin{array}{l}\text { Domowa opieka medyczna } \\
\text { Brak odpowiedzi - } 2(5,3 \%)\end{array}$ & $0(0 \%)$ \\
\hline 7. & Pomoc w pracach domowych & $2(5,3 \%)$ \\
\hline 8. & $\begin{array}{l}\text { Kształcenie specjalne } \\
\text { Brak odpowiedzi - } 2(5,3 \%)\end{array}$ & $1(2,6 \%)$ \\
\hline 9. & Organizowana dzienna aktywność & $1(2,6 \%)$ \\
\hline 10. & $\begin{array}{c}\text { Dom spokojnej starości/zakład opiekuńczo-wychowawczy } \\
\text { Brak odpowiedzi - } 2(5,3 \%)\end{array}$ & $0(0 \%)$ \\
\hline 11. & Inna duża instytucja opiekuńcza & $0(0 \%)$ \\
\hline 12. & Usługi dla osób z uszkodzonym wzrokiem & $2(5,3 \%)$ \\
\hline 13. & $\begin{array}{l}\text { Usługi dla osób z uszkodzonym słuchem wykraczające poza rutynowe badania } \\
\qquad \text { Brak odpowiedzi - } 2(5,3 \%)\end{array}$ & $3(7,9 \%)$ \\
\hline 14. & $\begin{array}{l}\text { Lekarz rodzinny (poza rutynowymi badaniami) } \\
\text { Brak odpowiedzi - } 2(5,3 \%)\end{array}$ & $2(5,3 \%)$ \\
\hline 15. & $\begin{array}{l}\text { Pediatra (poza rutynowymi badaniami) } \\
\text { Brak odpowiedzi }-2(5,3 \%)\end{array}$ & $4(10,6 \%)$ \\
\hline 16. & $\begin{array}{c}\text { Lekarz specjalista (określ jaki) } \\
\text { laryngolog (3), nefrolog (2), neurolog (2), kardiolog (4), ortopeda (5), gastrolog (1), okulista (4), } \\
\text { alergolog (4), dermatolog (1), urolog (1), endokrynolog (1), pulmonolog (1), ortodonta (2), brak } \\
\text { określenia (2) }\end{array}$ & $13(34,2 \%)$ \\
\hline 17. & $\begin{array}{c}\text { Psychiatra } \\
\text { Brak odpowiedzi - } 2(5,3 \%)\end{array}$ & $7(18,4 \%)$ \\
\hline 18. & $\begin{array}{c}\text { Psycholog } \\
\text { Brak odpowiedzi - } 2(5,3 \%)\end{array}$ & $11(28,9 \%)$ \\
\hline 19. & $\begin{array}{l}\text { Poradnictwo /psychoterapia } \\
\text { Brak odpowiedzi - } 2(5,3 \%)\end{array}$ & $6(15,8 \%)$ \\
\hline 20. & $\begin{array}{c}\text { Dietetyk } \\
\text { Brak odpowiedzi - } 2 \text { (5,3\%) }\end{array}$ & $4(10,6 \%)$ \\
\hline 21. & $\begin{array}{c}\text { Terapia logopedyczna } \\
\text { Brak odpowiedzi - } 2(5,3 \%)\end{array}$ & $18(47,4 \%)$ \\
\hline 22. & $\begin{array}{l}\text { Pomoc przy zaburzeniach zachowania/ wsparcie behawioralne } \\
\text { Brak odpowiedzi - } 2(5,3 \%)\end{array}$ & $2(5,3 \%)$ \\
\hline 23. & $\begin{array}{l}\text { Terapia zajęciowa } \\
\text { Brak odpowiedzi - } 2 \text { (5,3\%) }\end{array}$ & $6(15,8 \%)$ \\
\hline 24. & $\begin{array}{c}\text { Fizjoterapia } \\
\text { Brak odpowiedzi - } 2 \text { (5,3\%) }\end{array}$ & $2(5,3 \%)$ \\
\hline 25. & $\begin{array}{l}\text { Inne (określ jakie) } \\
\text { Terapia SI (1) } \\
\text { Rehabilitacja (1) }\end{array}$ & $2(5,3 \%)$ \\
\hline
\end{tabular}


Tabela 4. Przyczyny, dla których rodziny $(n=10)$ nie mogą korzystać z pomocy w ramach specjalistycznego wsparcia (FQOLS-2006/V - część A. 2c).

Table 4. Reasons why families $(n=10)$ cannot receive support from disability-related services (FQOLS-2006/V - part A. 2c).

\begin{tabular}{ccc}
\hline & Określenie przyczyny & $\begin{array}{c}\text { Liczba rodzin } \\
\text { dzieckiem z APD } \\
(\boldsymbol{n}=10)\end{array}$ \\
\hline 1. & Długi czas oczekiwania na usługi & $8(80 \%)$ \\
\hline 2. & Usługi, które są obecnie oferowane, nie są wystarczające & $1(10 \%)$ \\
\hline 3. & Usługi te nie są dostępne w naszej okolicy (proszę wymienić) & $3(30 \%)$ \\
\hline 4. & Problemem jest transport & $0(0 \%)$ \\
\hline 5. & Mamy trudności z dotarciem na umówione spotkania ze względu & $0(0 \%)$ \\
\hline 6. & na trudności w poruszaniu się & $2(20 \%)$ \\
\hline 7. & Mamy trudności w zrozumieniu tego, co mówią specjaliści & $0(0 \%)$ \\
\hline 8. & Nieżyczliwe traktowanie przez personel & $0(0 \%)$ \\
\hline 10. & Mamy różne przekonania na temat usług wspierających & $1(10 \%)$ \\
\hline
\end{tabular}

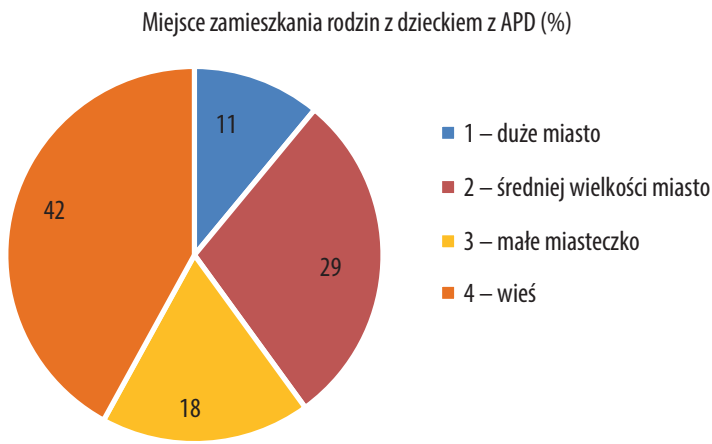

Rycina 5. Miejsce zamieszkania rodzin z dzieckiem z APD: 1 - duże miasto, 2 - średniej wielkości miasto, 3 - małe miasteczko, 4 - wieś.

Figure 5. Residence of families with a child with APD: 1 - a large city, 2 - a medium-sized city, 3 - a small town, 4 - a village.

Emocjonalny stosunek rodziców dziecka z APD do miejsca zamieszkania (\%)

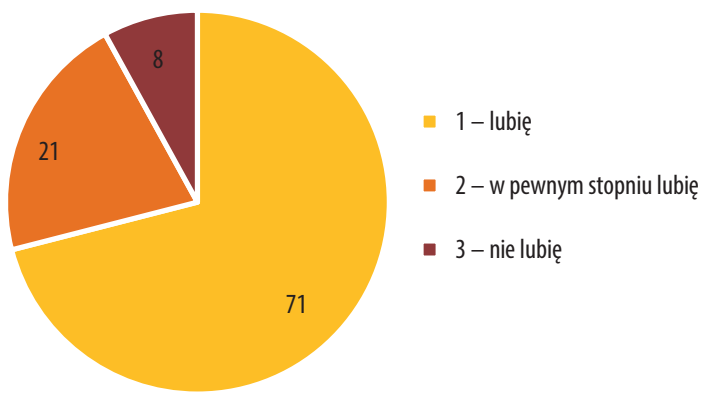

Rycina 6. Emocjonalny stosunek rodziców do miejsca

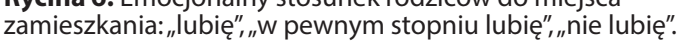

Figure 6. An emotional attitude of parents to their residence: 'like', 'somewhat like,',don't like'

\section{Wsparcie $w$ ramach specjalistycznych ustug}

Dziedzina ta odgrywa ważną rolę, zwłaszcza w rodzinach $\mathrm{z}$ dziećmi z różnymi problemami. Obejmuje różne rodzaje i formy wsparcia, np. wsparcie finansowe, poradnictwo rodzinne, wsparcie rehabilitacyjne czy terapeutyczne dla dziecka. Okazuje się, że w rodzinach z dzieckiem z APD Wsparcie w ramach specjalistycznych usług znalazło się wśród dziedzin życia najniżej ocenionych. W części dotyczącej rodzaju usług, z jakich korzystają objęte badaniami rodziny (część A FQOLS-2006/V) najczęściej wymieniane są usługi adresowane do dzieci: terapia logopedyczna (47\%), opieka medyczna świadczona przez lekarzy różnych specjalności (34\%), opieka psychologiczna (29\%). Zwraca uwagę, że prawie $20 \%$ rodzin korzysta $z$ pomocy lekarza psychiatry ( $w$ ankiecie pytanie dotyczy wszystkich członków rodziny), a z profesjonalnej pomocy psychologicznej (poradnictwo, psychoterapia) - około $15 \%$ (tabela 3 ).

Na pytanie, czy istnieją takie usługi specjalistyczne, których rodzina potrzebuje, lecz ich nie otrzymuje, twierdząco odpowiedziało 10 (26\%) rodziców. Pozostali, czyli zdecydowana większość badanych rodzin, korzystają z usług zgodnie $\mathrm{z}$ istniejącymi w tym zakresie potrzebami. Wśród przyczyn, z powodu których rodziny z dzieckiem z APD nie mogą korzystać z pomocy w ramach specjalistycznego wsparcia, najczęściej wymieniany jest długi czas oczekiwania na usługi (80\%), a w dalszej kolejności - brak dostępności danych usług $\mathrm{w}$ miejscu zamieszkania rodziny (30\%) (tabela 4).

\section{Interakcje społeczne}

W tym obszarze oceniane jest funkcjonowanie rodziny w lokalnej społeczności (FQOLS-2006/IX/część A), a uczestniczący w badaniach odnoszą się do następujących zagadnień: a) przynależność członków rodziny do różnych 
grup, klubów i organizacji, b) doświadczenia dyskryminacji członków rodziny, c) miejsce zamieszkania (wieś, małe miasteczko, średniej wielkości miasto, duże miasto), d) emocjonalny stosunek do miejsca zamieszkania.

Przynależność do różnych grup, klubów i organizacji zgłosiło 17 rodzin (45\%), a zdecydowana większość wskazywanych form aktywności wiąże się ze sportem (ponad połowa badanych), uczestnictwem w grupie tanecznej, nauką języka angielskiego, ZHP itp. Brak przynależności do jakiejkolwiek grupy zgłosiło nieco ponad 50\% rodzin.

Trzy (8\%) rodziny z dzieckiem z APD, a więc stosunkowo nieliczne, zgłosiły akty dyskryminacji, których doświadczyły w swoich społecznościach lokalnych. Rodzice pisali m.in.: „Mieszkamy na wsi, ale «swoi» trzymają się tylko razem. Są też zatargi z pokoleniem starszym i młodzi trzymają stronę «swoich»" czy „Antoni ze względu na wycofanie i otyłość jest wyśmiewany. Umniejszana jest jego wartość (nawet przez dorosłych)".

Badane rodziny mieszkają najczęściej na wsi (42\%) lub w średniej wielkości mieście (29\%). Z dużych miast pochodzi $11 \%$ rodzin, a z małych miasteczek - 18\% (rycina 5).

Pozytywny stosunek badanych rodziców do swojego miejsca zamieszkania, wyrażony słowami „lubię mieszkać w tej społeczności”, zadeklarowało 27 (71\%) osób. Odpowiedź: „Lubię w pewnym stopniu” swoje miejsce zamieszkania zaznaczyło 8 (21\%) rodziców (rycina 6). Natomiast zdecydowanie negatywny stosunek do miejsca zamieszkania miało 3 (8\%) rodziców dzieci z APD.

\section{Dyskusja}

Przedmiotem badań była jakość życia rodzin z dzieckiem z APD oceniana z zastosowaniem kwestionariusza FQOLS-2006, w których poddano także analizie jakościowo-ilościowej trzy obszary życia rodzin o najniższej ich ocenie pod względem jakości: Wsparcie innych osób, Wsparcie $w$ ramach specjalistycznych ustug oraz Interakcje społeczne. Porównano również wyniki z danych ilościowych (FQOLS-2006/część B) otrzymane przez rodziny z dzieckiem z APD do uzyskanych przez rodziny $z$ dziećmi $z$ innymi niepełnosprawnościami [10], a także rodziny małych dzieci głuchych [11].

Jakość życia rodzin z dzieckiem z APD ogółem na poziomie tendencji jest wyższa niż rodzin $\mathrm{z}$ dzieckiem niepełnosprawnym [10], lecz podobna do jakości życia rodzin w ocenie matek małych dzieci głuchych [11]. Można sądzić, że jest ona nieco niższa niż w rodzinach $\mathrm{z}$ dziećmi o typowym rozwoju. Jednakże z dużą ostrożnością należy traktować tę sugestię, ponieważ jak dotąd nie zostały opracowane polskie normy dla kwestionariusza FQOLS-2006 wykorzystanego w badaniach nad jakością życia rodzin z dzieckiem z APD. Wynik ogólnej jakości życia rodzin $\mathrm{z}$ dzieckiem z APD wyższy niż $\mathrm{w}$ przypadku rodzin $\mathrm{z}$ dzieckiem $\mathrm{z}$ niepełnosprawnością (tendencja) wiąże się przede wszystkim z lepszym jakościowo funkcjonowaniem tych rodzin w sferze aktywności zawodowej jej członków, co zaprezentowano na wykresie 1.
Rodzice dzieci z APD najwyżej oceniają swoje rodziny w dziedzinie Relacji rodzinnych, Zdrowia oraz Kariery zawodowej. Dwie pierwsze dziedziny pozostają na tej samej lub podobnej pozycji także $\mathrm{w}$ rodzinach $\mathrm{z}$ dziećmi z różnymi niepełnosprawnościami i zaburzeniami neurorozwojowymi, nie tylko w Polsce [6,9-11]. Kariera zawodo$w a$ w rodzinach $\mathrm{z}$ dziećmi niepełnosprawnymi zazwyczaj oceniana jest nieco niżej przez rodziców (głównie matki) czy innych członków rodziny. Niewykluczone, że sytuacja taka wiąże się z faktem, że to zazwyczaj matki rezygnują z aktywności zawodowej, ograniczają lub w ogóle jej nie podejmują, przynajmniej okresowo, gdy dowiadują się o niepełnosprawności dziecka [35-39]. Pogorszenie jakości życia rodzin z dziećmi niepełnosprawnymi w omawianej sferze może też być skutkiem rosnących nierzadko obciążeń finansowych, wobec których stają rodzice, zwłaszcza ojcowie, związanych z leczeniem, rehabilitacją czy pomocą specjalistyczną dziecku z niepełnosprawnością [35-40].

Analizując wyniki badań w odniesieniu do rodzin z dzieckiem z APD, można stwierdzić, że problemy dziecka nie przyczyniły się do znaczącej modyfikacji obszaru Kariera zawodowa, pomimo że rodzice doświadczają w różnym zakresie trudności związanych z byciem rodzicem dziecka z APD [22,29-30].

Najniższą jakość życia w rodzinach z dzieckiem z APD odnotowano w obszarach: Wsparcie innych osób, Interakcje społeczne oraz Wsparcie w ramach specjalistycznych ustug. $\mathrm{W}$ świetle badań nad wsparciem społecznym rodzin $\mathrm{z}$ dziećmi z niepełnosprawnością nie zaskakują niskie oceny jakości życia w obszarze Wsparcia innych osób (zarówno praktycznego, jak i emocjonalnego), a także niska jakość Interakcji społecznych rodzin w społeczności lokalnej - są one zbieżne z innymi wynikami badań $[6,9,10-11]$. Co interesujące, w obszarze Wsparcie innych osób rodzice z dzieckiem z APD nadają mu najniższe Znaczenie, podejmują najmniej Inicjatywy względem innych dziedzin życia rodziny, uzyskują najmniej Osiągnięć i Stabilizacji, a także - niejako w konsekwencji - czerpią najmniej Satysfakcji. Prowadzi to do konkluzji, że na niską jakość życia rodzin w ww. sferach wpływa nie tylko niepełnosprawność dziecka, lecz także inne problemy i deficyty obecne u dzieci, do jakich należą m.in. zaburzenia przetwarzania słuchowego, mające charakter neurorozwojowy, które $z$ definicji nie stanowią niepełnosprawności. Oznacza to, że mechanizmów opisanego stanu rzeczy należy też poszukiwać w rodzinie i jej trudnościach w adaptacji do problemów u dziecka [11].

Szczególną uwagę - w przypadku rodzin z dzieckiem z APD - zwracają natomiast niskie wyniki w ocenie jakości życia rodzin w sferze Wsparcie $w$ ramach specjalistycznych usług. Usługi, które otrzymuje rodzina (w tym dziecko z APD) zostały względem innych obszarów życia ocenione niemal najniżej, podczas gdy wsparcie tego typu w rodzinach dzieci z różnymi rodzajami niepełnosprawności należy do jakościowo najlepiej ocenianego obszaru [6,9-11]. Relacje rodziców dzieci z różnymi niepełnosprawnościami, pozyskane w badaniach jakościowych [np. 6,36,41], stanowią potwierdzenie wyników zebranych za pomocą kwestionariusza FQOLS-2006, wskazując na szczególną, pozytywną rolę specjalistów i udzielanego przez nich wsparcia - zarówno dziecku, jak i jego rodzicom. 
Należałoby w tym miejscu postawić pytanie, o czym informuje ten odmienny względem rodzin $\mathrm{z}$ dzieckiem $\mathrm{z}$ niepełnosprawnością wynik, wskazujący na bardzo niską jakość Wsparcia $w$ ramach specjalistycznych usług $\mathrm{w}$ rodzinach z dzieckiem z APD. Z pewnością pokazuje pewien deficyt istniejący w przekonaniu rodziców w tej dziedzinie życia, jak i związaną z nim ich niską Satysfakcję.

Z jakościowo-ilościowej analizy danych dotyczących omawianej sfery (FQOLS-2006/V/część A) wynika, że rodziny dzieci z APD najczęściej korzystają z: opieki medycznej (54\%), usług logopedycznych (47\%) i psychologicznych (29\%). O kondycji rodziny z dzieckiem z APD mówią także dane pokazujące, że $20 \%$ rodzin korzysta z opieki lekarza psychiatry. Dla porównania - z poradnictwa psychologicznego i psychoterapii korzysta nieco mniej rodzin dzieci z APD (15\%). Z badań wynika też, że $25 \%$ rodzin z dzieckiem z APD z różnych powodów nie korzysta ze specjalistycznych usług, których potrzebuje (dziecko z APD lub jego rodzice/rodzina), np. nie ma do nich dostępu, ponieważ „brak danych usług w miejscu zamieszkania” (30\%), lub przyczyną jest „długi czas oczekiwania na wizytę" (80\%).

Zaprezentowane powyżej wyniki uzyskane w obszarze Wsparcie $w$ ramach specjalistycznych usług w rodzinach z dzieckiem z APD dają podstawy do tego, by uznać, że dotychczasowy sposób postępowania (terapia/rehabilitacja) w przypadku dziecka z APD i jego rodziny wymaga zmian.

Należałoby wyjść poza obecnie dominujący model - skoncentrowany przede wszystkim na percepcji słuchowej dziecka z APD i jego trudnościach związanych z tą sferą - którego skutkiem jest zastosowanie prawie wyłącznie strategii kompensujących deficyty słuchowe dziecka, m.in. treningów słuchowych czy terapii psychologiczno-pedagogicznych ukierunkowanych na usprawnianie uczenia się i komunikowania [30,32,42-45]. Jednakże, jak wynika $\mathrm{z}$ dotychczasowych doniesień i doświadczeń, niezwykle istotne są - często występujące w tej grupie dzieci - także zaburzenia rozwoju mowy i języka [19,23-26], zaburzenia rozwoju psychomotorycznego [25-26] oraz trudności związane ze sferą społeczno-emocjonalną $[22,46]$. Kiedy zatem u dziecka zostają zdiagnozowane zaburzenia przetwarzania słuchowego, wsparciem w ramach specjalistycznych usług powinna zostać objęta także jego rodzina (rodzice) - w myśl podejścia skoncentrowanego na rodzinie (FCA), którego efektywność została już dowiedziona w odniesieniu do różnych problemów, jakie mogą występować u dzieci [1-3]. Niska jakość zgłaszana przez rodziców dzieci z APD w sferze Wsparcie w ramach specjalistycznych usług może być także wyrazem różnego rodzaju trudności samych rodziców (rodzin), którzy nie otrzymują potrzebnego im wsparcia $\mathrm{w}$ ramach specjalistycznych usług.

\section{Podsumowanie i wnioski}

Jakość życia rodzin z dzieckiem z APD, badana za pomocą kwestionariusza FQOLS-2006, została najniżej oceniona w dziedzinach związanych ze wsparciem społecznym, w tym ze Wsparciem $w$ ramach specjalistycznych usług. Wynik taki wskazuje, że oferta specjalistyczna powinna obejmować także rodziców (rodzinę) i zawierać różne formy interwencji psychologicznej, np. doradztwo psychologiczne, psychoterapię, warsztaty psychoedukacyjne czy grupy wsparcia dla rodziców, co będzie sprzyjać lepszemu funkcjonowaniu rodziny, a tym samym rozwojowi dziecka z APD. Aby podnieść jakość życia w dziedzinie Wsparcie $w$ ramach specjalistycznych usług, należałoby także rozszerzyć ofertę obejmującą dzieci z APD - oprócz oddziaływań ukierunkowanych na percepcję słuchową i trudności z nią związane, wynikające $\mathrm{z}$ centralnych zaburzeń przetwarzania słuchowego, zapewnić całościowe wspieranie dzieci z APD w rozwoju, ponieważ tylko w ten sposób można znacząco polepszyć ich funkcjonowanie poznawcze, w tym językowe, oraz emocjonalno-społeczne zarówno w środowisku rodzinnym, jak i szkolnym. Reasumując, podejście skoncentrowane na rodzinie zastosowane wobec rodzin $\mathrm{z}$ dzieckiem $\mathrm{z}$ APD mogłoby zaowocować poprawą sytuacji tych rodzin w sferach, które zostały najniżej ocenione.

\section{Piśmiennictwo}

1. Dalvand H, Rassafiani M, Bagheri H. Family Centered Approach: A literature review. Modern Rehabilitation, 2014; 8(1).

2. Francisco Mora C, Ibáñez A, Balcells-Balcells A. State of the Art of Family Quality of Life in Early Care and Disability: A Systematic Review. IJERPH, 2020; 17(19): 7220.

3. King G, Kertoy M, King S, Law M, Rosenbaum P, Hurley P. A measure of parents' and service providers' beliefs about participation in family-centered services. Child Health Care, 2003; 32(3): 191-214.

4. Brown RI, Brown I. Family Quality of Life, w: Encyclopedia of Quality of Life and Well-Being Research. Michalos AC (red.). Dordrecht: Springer; 2014.

5. Brown RI, Kyrkou MR, Samuel PS. Family quality of life, w: Health Care for People with Intellectual and Developmental Disabilities across the Lifespan. Rubin IL, Merrick J, Greydanus DE, Patel DR (red). Basel: Springer; 2016, s. 2065-82.

6. Zasępa E, Wołowicz A. Jakość życia rodzin z dzieckiem z niepełnosprawnością intelektualną. Warszawa: Wydawnictwo Akademii Pedagogiki Specjalnej; 2010.
7. Brown I, Brown RI, Baum NT, Isaacs BJ, Myerscough T, Neikrug S i wsp. Family Quality of Life Survey: Main caregivers of people with intellectual or developmental disabilities. Zasępa E, Wapiennik E, Wołowicz A (tłum.). Toronto: Surrey Place Centre; 2006.

8. Hu X, Summers JA, Turnbull A, Zuna N. The quantitative measurement of family quality of life: A review of available instruments. J Intellect Disabil Res, 2011; 55: 1098-114.

9. Schertz M, Karni-Visel Y, Tamir A, Genizi J, Roth D. Family quality of life among families with a child who has a severe neurodevelopmental disability: Impact of family and child socio-demographic factors. Res Dev Disabil, 2016; 53: 95-106.

10. Otapowicz D, Sakowicz-Boboryko A, Wyrzykowska-Koda D. Niepełnosprawność a jakość życia rodziny. Pogranicze. Studia Społeczne, 2016; XXVIII: 101-15.

11. Kobosko J, Ganc M, Paluch P, Jędrzejczak WW, Geremek-Samsonowicz A, Skarżyński H. Jakość życia rodziny z małym dzieckiem głuchym. Now Audiofonol, 2020; 9(1): 19-32. 
12. Kobosko J. Relacja matka-dziecko a zaburzenia rozwoju językowego u młodzieży głuchej. Przegląd Psychologiczny, 2009; 52(3): 327-42.

13. Wzorek A. Rodzina $\mathrm{z}$ dzieckiem $\mathrm{z}$ zaburzeniami słuchu - spojrzenie systemowe. Psychoterapia, 2010; 4(151): 53-64.

14. American Speech-Language-Hearing Association (ASHA). (Central) Auditory processing disorders. Technical report, 2005; http://www.ak-aw.de/sites/default/files/2016-12/ASHA_ CAPD_2005.pdf [dostęp: 14.06.2021].

15. Chermak GD, Musiek FE. Central auditory processing disorders: New perspectives. San Diego: Singular; 1997.

16. Katz J. Central Test Battery. Vancouver: Precision Acoustis.; 2001.

17. Kurkowski ZM. Audiogenne uwarunkowania zaburzeń komunikacji językowej. Lublin: UMCS; 2013.

18. Skoczylas A, Lewandowska M, Pluta A, Kurkowski ZM, Skarżyński H. Ośrodkowe zaburzenia słuchu - wskazówki diagnostyczne i propozycje terapii. Now Audiofonol, 2012; 1(1): 11-18.

19. Skoczylas A. Lingwistyczne aspekty zaburzeń przetwarzania słuchowego u dzieci i ich rehabilitacja z perspektywy logopedy. Now Audiofonol, 2018; 7(4): 51-7.

20. Wit E de, Dijk P van, Hanekamp S, Visser-Bochane MI, Steenbergen B, Schans CP van der, Luinge MR. Same or different: The overlap between children with auditory processing disorders and children with other developmental disorders: A systematic review. Ear Hear, 2018; 39(1): 1-19.

21. Lewandowska M, Milner R, Ganc M, Włodarczyk E, Dołżycka J, Skarżyński H. Development of central auditory processes in Polish children and adolescents at the age from 7 to 16 years. Curr Psychol, 2021; 1-18.

22. Rostkowska J, Kobosko J, Kłonica KL. Problemy emocjonalno-społeczne i behawioralne u dzieci z centralnymi zaburzeniami przetwarzania słuchowego (CAPD) w ocenie rodziców. Now Audiofonol, 2013; 2(1): 29-35.

23. Samsonowicz K, Skoczylas A, Fludra M, Geremek-Samsonowicz A. Trudności językowe i szkolne u 8-letniego chłopca z zaburzeniami przetwarzania słuchowego - studium przypadku. Now Audiofonol, 2020; 3(4): 47-54.

24. Vilela N, Barrozo TF, de Oliveira Pagan-Neves L, Sanches SGG, Wertzner HF, Carvallo RMM. The influence of (central) auditory processing disorder on the severity of speech-sound disorders in children. Clinics, 2016; 71(2): 62-8.

25. Ganc M, Kobosko J, Jedrzejczak WW, Skoczylas A, Geremek-Samsonowicz A, Skarżyński H. Rozwój psychoruchowy dzieci z centralnymi zaburzeniami przetwarzania słuchowego i nieprawidłowym rozwojem mowy rozpoczynających edukację szkolną. Międzynarodowa Konferencja Pedagogiki Specjalnej z cyklu OSOBA „Jedność w różnorodności - idea i rzeczywistość. 30 lat edukacji integracyjnej w Polsce”, 26-27 września 2019 r., Warszawa (plakat).

26. Ganc M, Kobosko J, Jędrzejczak WW, Skoczylas A, Geremek-Samsonowicz A. Karty Oceny Rozwoju Psychoruchowego (KORP) - opis narzędzia i prezentacja jego wykorzystania na przykładzie trzech studiów przypadku dzieci z zaburzeniami słuchu. Now Audiofonol, 2019; 8(3): 58-67.

27. Eschenbeck H, Gillé V, Heim-Dreger U, Schock A, Schott A. Daily stress, hearing-specific stress and coping: self-reports from deaf or hard of hearing children and children with auditory processing disorder. J Deaf Stud Deaf Educ, 2017; 22(1): 49-58.
28. Kobosko J, Fludra M, Skoczylas A, Rosińska A, Czajka N, Geremek-Samsonowicz A, Skarżyński H. Stres a osobowość - badania nad matkami dzieci głuchych i matkami dzieci z centralnymi zaburzeniami przetwarzania słuchowego. XLII Krajowa Konferencja Naukowo-Szkoleniowa „Problemy otolaryngologii dziecięcej w codziennej praktyce”, 3-5 listopada 2019 r., Kajetany. Now Audiofonol, 2019; 8(4): 75 (plakat i abstrakt).

29. Grudzień D, Urban I, Skarżyński PH. Sytuacja rodzinna dzieci z centralnymi zaburzeniami przetwarzania słuchowego - doniesienia z badań, w: Zmysły w komunikacji. Wszystkie zmysły prowadzą do mózgu. Kazek B, Wojciechowska J (red.). Gdańsk: Harmonia Universalis; 2014, s. 61-78.

30. Czajka N, Grudzien D, Pluta A i wsp. Efekty terapii Stymulacji Percepcji Słuchowej (SPS-S) u dzieci z zaburzeniami koncentracji uwagi słuchowej oraz centralnymi zaburzeniami przetwarzania słuchowego. Now Audiofonol, 2012; 1(1): 79-86.

31. Plopa M. Skala Postaw Rodzicielskich. Warszawa: Vizja Press \& IT; 2008.

32. Sobańska J, Szuber D, Skarżyński PH. Stymulator Polimodalnej Percepcji Sensorycznej Skarżyńskiego w rehabilitacji dzieci z zaburzeniami przetwarzania słuchowego - analiza wyników badań na materiale Podkarpackiego Centrum Słuchu i Mowy Medincus w Rzeszowie. Now Audiofonol, 2020; 9(1).

33. Włodarczyk EA, Szkiełkowska A, Skarżyński H, Miaśkiewicz B, Skarżyński PH. Reference values for psychoacoustic tests on Polish school children 7-10 years old. PLoS ONE, 2019; 14(8): e0221689.

34. Ho E, James N, Brown I, Firkowska-Mankiewicz A, Zasępa E, Wołowicz A, Wapiennik E. Family quality of life of Polish families with a member with intellectual disability, J Intellect Disabil Res, 2013; 19(2): 36-41.

35. Kosmalowa J. Pomoc rodzinie dziecka $z$ wadą słuchu jako podstawowy element oddziaływań w procesie wczesnej interwencji. Audiofonologia, 2002; XXI: 129-38.

36. Baran J. Problemy i konteksty wychowania dzieci z uszkodzonym słuchem w przekazach ich słyszących matek. Kraków: Wydawnictwo Naukowe Uniwersytetu Pedagogicznego; 2012.

37. Kobosko J. Psychologiczne implikacje głuchoty dziecka w rodzinie i środowisku szkolnym, w: Edukacja głuchych. Sak M. (red.). Warszawa: Rzecznik Praw Obywatelskich; 2014, s. 44-66.

38. Komorowska O. Aktywność życiowa rodziców wychowujących dziecko z niepełnosprawnością jako istotny element ochrony ich zdrowia. Ekonomia, 2018; 24(2): 61-72.

39. Niedbalski J. Macierzyństwo i ojcostwo w perspektywie podejmowania roli rodzica dziecka $\mathrm{z}$ niepełnosprawnością. Przegląd Socjologii Jakościowej, 2020; 16(3): 18-39.

40. Kornas-Biela D, Tupaj K. Ojcostwo w samoocenie mężczyzn wychowujących dzieci z uszkodzonym słuchem. Część II. Badania empiryczne. Roczniki Pedagogiczne, 2020; 12(3): 173-90.

41. Sakowicz-Boboryko A. Wspieranie rodziców w rehabilitacji dzieci z niepełnosprawnością słuchową. W kręgu odpowiedzialności. Warszawa: Wydawnictwo Akademickie Żak; 2016.

42. Senderski A. Rozpoznawanie i postępowanie w zaburzeniach przetwarzania słuchowego u dzieci. Otorynolaryngologia, 2014; 13(2): 77-81.

43. Rostkowska J. Aktywny Trening Słuchowy - element terapii pacjentów z zaburzeniami przetwarzania słuchowego (APD). Now Audiofonol, 2014; 3(4): 39-43.

44. Kruczyńska-Werner A. Centralne zaburzenia przetwarzania słuchowego - aktualne możliwości terapii dostępne w Polsce. Logopedia, 2018; 47(1): 231-45. 
45. Bieńkowska KI, Zaborniak-Sobczak M, Senderski A, Jurczak P. Terapia centralnych zaburzeń przetwarzania słuchowego - przegląd metod i narzędzi w kontekście wsparcia edukacyjnego uczniów. Niepełnosprawność-Dyskursy Pedagogiki Specjalnej, 2019; 36: 103-24.
46. Rostkowska J, Wojewódzka B. Dzieci z zaburzeniem przetwarzania słuchowego, w: Wspieranie rozwoju umiejętności społecznych dzieci w normie rozwojowej i dzieci ze specjalnymi potrzebami. Szurowska B, Jegier A (red.). Warszawa: Wydawnictwo Difin; 2017, s. 104-13. 
